\title{
Facile Synthesis of a Nickel(0) Phosphine Complex at Ambient Temperature
}

Received 00th January 20xx, Accepted 00th January 20xx DOI: $10.1039 / x 0 \times x 00000 x$

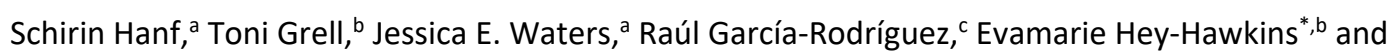
Dominic S. Wright ${ }^{*}$ a
The reaction of the bis(methoxy)-2-pyridyl-phosphine $(\mathrm{MeO})_{2} \mathrm{P}(2-\mathrm{py})(1)$ with $\left[\mathrm{Ni}(\mathrm{MeCN})_{6}\right]\left(\mathrm{BF}_{4}\right)_{2}$ leads to the unexpected single-step reduction of $\mathrm{Ni}^{\prime \prime}$ and the formation of a tetrahedral nickel(0) complex $\left[\left\{(\mathrm{MeO})_{2} \mathrm{P}(2-\mathrm{py}-\mathrm{H})\right\}_{2}\left\{(\mathrm{MeO})_{2} \mathrm{P}(2-\mathrm{py})\right\}_{2} \mathrm{Ni}\right]\left(\mathrm{BF}_{4}\right)_{2}$ (2). The redox activity is probably induced by the decomposition of the tetrafluoroborate anion; NMR spectroscopic studies point towards a fluoride-assisted oxidation of the 2-pyridyl-phosphine ligand, with associated reduction of the metal.

In the past two decades, there has been increasing interest in the use of homogeneous nickel catalysts in a broad range of organic transformations, such as $\mathrm{C}-\mathrm{H}$ bond activation, Heck coupling, and the reductive- and cross-coupling reactions of halo-alkanes. ${ }^{1}$ One obvious motivation is the low cost of nickel compared to more commonly used palladium and platinum catalysts in Group 10. However, the atomic characteristics of nickel itself, being smaller, more electronegative and harder (based on the hard and soft acids and bases principle) than the $4 d / 5 d$ elements, also gives it distinctly different reactivity, for example, facile oxidative addition and $\beta$-migratory insertion as well as the potential for radical reaction pathways. Most nickelbased catalytic systems involve $\mathrm{Ni}^{11} / \mathrm{Ni}^{0}$ reaction cycles, with $\mathrm{Ni}^{0}$ species being the active catalytic species. Although $\mathrm{Ni}^{\prime \prime}$ precatalysts can be employed, stable $\mathrm{Ni}^{0}$ catalysts or precatalysts such as the ubiquitous $\left[\mathrm{Ni}(\mathrm{COD})_{2}\right](\mathrm{COD}=1,5-$ cyclooctadiene) feature strongly in this area, ${ }^{2-11}$ and the development of new $\mathrm{Ni}^{0}$ species for selective organic transformations is a growing field of research. ${ }^{12}$

\footnotetext{
a. Dr. S. Hanf, Prof. Dr. D. S. Wright, Chemistry Department, Cambridge University, Lensfield Road, CB2 1EW, Cambridge, UK. E-mail:dsw1000@cam.ac.uk.

b. Dr. T. Grell, Prof. Dr. E. Hey-Hawkins, Institute of Inorganic Chemistry, Faculty of Chemistry and Mineralogy, Leipzig University, Johannisallee 29, 04103 Leipzig, Germany.E-mail: hey@uni-leipzig.de

c. Dr. R. García-Rodríguez, GIR MIOMeT-IU Cinquima-Química Inorgánica Facultad de Ciencias, Universidad de Valladolid, Campus Miguel, Delibes, 47011 Valladolid, Spain.

Electronic Supplementary Information (ESI) available: experimental details,

characterisation, supporting spectra, and crystallographic data (CCDC: 1956107). See DOI: $10.1039 / x 0 x \times 00000 x$
}

Commonly, tetracoordinate nickel(0) complexes of the type [NiL4] ( $\mathrm{L}=$ trialkyl-, triaryl-, alkyl-aryl-phosphines) have been synthesised from labile $\mathrm{Ni}^{0}$ precursors, such as $\left[\mathrm{Ni}(\mathrm{COD})_{2}\right]$ or $\left[\mathrm{Ni}(\mathrm{CO})_{2}(\mathrm{COD})\right] .^{13}$ However, the use of these very reactive and unstable nickel( 0 ) species can be avoided using in situ reduction of a nickel(II) precursor, such as $\mathrm{NiCl}_{2}$ or $\left[\mathrm{NiX}_{2} \mathrm{~L}_{2}\right](\mathrm{X}=\mathrm{Cl}, \mathrm{Br}, \mathrm{L}=$ phosphine), with $\mathrm{Zn},{ }^{14} \mathrm{Na},{ }^{13} \mathrm{NaBH}_{4}{ }^{15}$ or $\mathrm{KC}_{8}{ }^{16}$ in the presence of a phosphine. The use of such strong reducing agents can be avoided in a number of phosphine-mediated reduction reactions. For example, nickel(II) halides are reduced by triethyl phosphite, $\mathrm{P}(\mathrm{OEt})_{3}$, in the presence of an amine and water to the tetrakis(triethylphosphite)nickel(0) complex, together with the corresponding ammonium salt and phosphine oxide (Scheme 1). ${ }^{17,18}$ This reaction can also proceed thermally using triethyl phosphite alone, ${ }^{19}$ although the mechanism is poorly understood.

$$
\mathrm{NiX}_{2}+5 \mathrm{P}(\mathrm{OEt})_{3} \stackrel{2 \mathrm{NR}_{3} / \mathrm{H}_{2} \mathrm{O}}{\longrightarrow}\left[\mathrm{Ni}\left\{\mathrm{P}(\mathrm{OEt})_{3}\right\}_{4}\right]+2 \mathrm{HNR}_{3} \mathrm{X}+\mathrm{O}=\mathrm{P}(\mathrm{OEt})_{3}
$$

Scheme 1. Reduction of nickel(II) halides in the presence of a triethyl phosphite, an amine and water $(X=\mathrm{Cl}, \mathrm{Br}, \mathrm{I}, \mathrm{R}=\mathrm{H}, \mathrm{Me})$.

A further development in this area has been the $\mathrm{F}^{-}$-induced reduction of $\mathrm{Pd}^{\prime \prime}$ to $\mathrm{Pd}^{0}$ in the presence of phosphines, a reaction which occurs via oxidation of the phosphines to difluorophosphoranes, $\mathrm{R}_{3} \mathrm{PF}_{2} \cdot{ }^{20-23} \mathrm{~A}$ related mechanism is thought to be involved in the reaction of $\left[\mathrm{Pd}(\mathrm{MeCN})_{4}\right]\left(\mathrm{BF}_{4}\right)_{2}$ with dppp [propane-1,3-diylbis(diphenylphosphane)], in which the $\mathrm{BF}_{4}^{-}$anion acts as the $\mathrm{F}^{-}$source to give the $\mathrm{Pd}^{0}$ complex $\left[\mathrm{Pd}(\mathrm{dppp})_{2}\right]$. However, attempts to extend this reaction to nickel were not successful. ${ }^{20}$ The tetrafluoroborate anion, which has previously been shown to be a suitable fluoride source for transition metal complexes, ${ }^{24,25}$ was identified as the fluoride source in the case of the $\mathrm{Pd}^{\prime \prime}$ to $\mathrm{Pd}^{0}$ reduction reaction. Relevant to the current work, the activity of $\mathrm{BF}_{4}^{-}$as a source of $\mathrm{F}^{-}$in transition metal chemistry is strongly influenced by the presence of a Lewis base, which is involved in the decomposition of the metal $\mathrm{BF}_{4}^{-}$species formed initially (presumably by the formation of an adduct of $\mathrm{BF}_{3}$ ). 
As part of a broader research program on the development of main group element-bridged 2-pyridyl ligands, we recently explored the synthesis and coordination chemistry of unsymmetrical phosphines of the type $(R O)_{x} \mathrm{P}(2-p y)_{3-x}(2-p y=$ 2-pyridyl; $x=1,2$ ) with a range of transition metal ions. ${ }^{26,27}$ Although ligands such as $(\mathrm{PhO})_{2} \mathrm{P}(2$-py) can coordinate to transition metals intact, here we show that interaction of the closely related ligand $(\mathrm{MeO})_{2} \mathrm{P}(2-\mathrm{py})(\mathbf{1})$ with $\left[\mathrm{Ni}(\mathrm{MeCN})_{6}\right]\left(\mathrm{BF}_{4}\right)_{2}$ at room temperature leads to the reduction of $\mathrm{Nill}^{l l}$ to $\mathrm{Ni}^{0}$. Our studies indicate that this involves the $\mathrm{BF}_{4}{ }^{-}$anion and is, to our knowledge, the first example of an $\mathrm{F}^{-}$-mediated reduction of $\mathrm{Ni}^{\prime \prime}$ to $\mathrm{Ni}^{0}$.

The reaction of $\left[\mathrm{Ni}(\mathrm{MeCN})_{6}\right]\left(\mathrm{BF}_{4}\right)_{2}$ with bis(methoxy)-2pyridyl-phosphine $(\mathrm{MeO})_{2} \mathrm{P}(2-\mathrm{py})(\mathbf{1})^{27}$ in acetonitrile under nitrogen produces a dark orange/brown solution. Crystallisation of the brown reaction residue from $\mathrm{MeOH}$ produces a crop of dark red crystals of the $\mathrm{Ni}^{0}$ complex $\left[\mathrm{Ni}(\mathbf{1})_{2}(\mathbf{1}-\mathrm{H})_{2}\right]\left(\mathrm{BF}_{4}\right)_{2}(\mathbf{2})$ in $37 \%$ yield (Scheme 2 ), which is isolated as the solvate $2 \cdot \mathrm{MeOH}$. Using the related ligand $\mathrm{P}(6-\mathrm{Me}-2-\mathrm{py})_{3}$ or the more closely related ligands $\left(\mathrm{Me}_{2} \mathrm{~N}\right)_{2} \mathrm{P}(2-\mathrm{py})$ and $(\mathrm{MeO}) \mathrm{P}(2-\mathrm{py})_{2}$ in place of phosphine 1 does not result in the corresponding $\mathrm{Ni}(0)$ complexes, suggesting that characteristics like the Lewis acidity and the $\sigma$-donor/ $\pi$-acceptor character are key to the reactivity of $1 .{ }^{28}$ The importance of the Lewis acidity of the $P$ centre in particular can be related to the proposed mechanism involved, and it is noteworthy that being the most Lewis acidic phosphine we have explored fluorination of the P-atom of $\mathbf{1}$ would produce the most stable intermediate (A, Scheme 3 ).

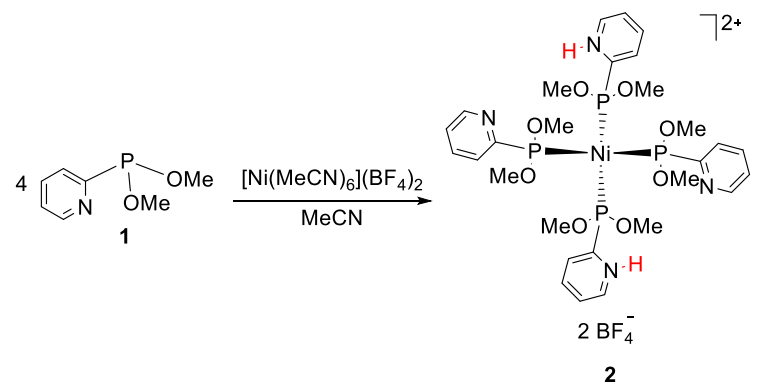
Scheme 2. Reaction of bis(methoxy)-2-pyridyl-phosphine (1) with nickel(II),
affording the nickel(0) complex 2.

The solid-state structure of the dicationic $\mathrm{Ni}^{0}$ complex of $\mathbf{2}$ is shown in Figure 1 (present in the crystalline solvate $2 \cdot \mathrm{MeOH}$ obtained from $\mathrm{MeOH}$ ). Within the complex, the nickel centre is tetrahedrally coordinated via the phosphorus bridgehead atoms of four ligand molecules 1 , with $\mathrm{Ni}-\mathrm{P}$ bond lengths of 2.1006(6)-2.1234(7) A. Similar Ni-P bond lengths have been found in previously reported tetrahedral nickel $(0)$ phosphine complexes. $^{29,30}$ A slight distortion of the tetrahedral coordination geometry is observed, with the $\mathrm{P}-\mathrm{Ni}-\mathrm{P}$ bond angles being in the range $106.16(2)-111.63(2)^{\circ}$. This appears to be largely a consequence of the protonation of two of the pyridyl-N atoms, which form strong intramolecular $\mathrm{N}-\mathrm{H} . . . \mathrm{N}$ hydrogen bonds with the unprotonated pyridyl- $\mathrm{N}$ atoms on

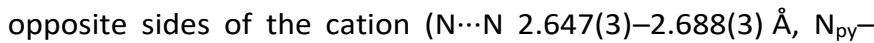
$\mathrm{H} \ldots \mathrm{N}_{\mathrm{py}} 1.76(3)-1.80(3) \AA ̊$ ). Similar, short intramolecular $\mathrm{N} \cdots \mathrm{N}$ distances have been found in bis(4-methylpyridine)hydrogen tetraphenylborate $(2.608 \AA$ ) $) .{ }^{31}$

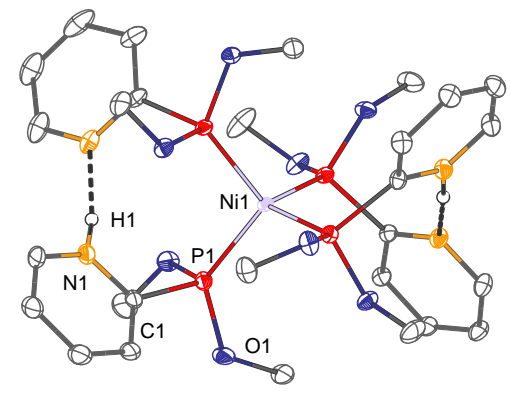

Figure 1. Structure of the dication $\left[\left\{(\mathrm{MeO})_{2} \mathrm{P}(2-\mathrm{py}-\mathrm{H})\right\}_{2}\left\{(\mathrm{MeO}){ }_{2} \mathrm{P}(2\right.\right.$ py) $\left.\}_{2} \mathrm{Ni}\right]\left(\mathrm{BF}_{4}\right)_{2} \cdot \mathrm{MeOH}(\mathbf{2} \cdot \mathrm{MeOH})$. Hydrogen atoms, $\mathrm{BF}_{4}{ }^{-}$counterions and the MeOH molecule are omitted for clarity. Displacement ellipsoids are drawn at the $30 \%$ probability level. Selected bond lengths $(\AA)$ and angles $\left({ }^{\circ}\right)$ : Ni-P 2.1006(6)$2.1234(7), \mathrm{P}-\mathrm{O} 1.597(2)-1.659(2), \mathrm{P}-\mathrm{C}_{\mathrm{py}} 1.837(2)-1.857(2), \mathrm{N}_{\mathrm{py}}-\mathrm{H} 1.76(3), 1.80(3)$

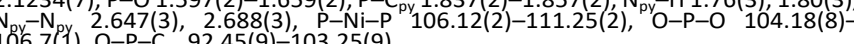
$106.7(1), \mathrm{O}-\mathrm{P}-\mathrm{C}_{\mathrm{py}} 92.45(9)-103.25(9)$

The expected diamagnetic character of $\mathbf{2}$ is shown in the ${ }^{31} \mathrm{P}$ and ${ }^{1} \mathrm{H}$ NMR spectra of the complex at room temperature in $\mathrm{CD}_{3} \mathrm{CN}$, which both contain sharp resonances (Figures $\mathrm{S} 4$ and $\mathrm{S5})$. Unfortunately, the signals of the $\mathrm{N}-\mathrm{H}$ protons in $\mathbf{2}$ are too broad to be observed in the ${ }^{1} \mathrm{H}$ NMR spectrum, despite the use of various solvents and solvent combinations and a wide NMR screening window. However, the solid-state IR spectrum shows a broad $\mathrm{N}-\mathrm{H}$ band at $1900-2250 \mathrm{~cm}^{-1}$ (Figure S9) consistent with the presence of a strong $\mathrm{N}_{\mathrm{py}}-\mathrm{H} \ldots \mathrm{N}_{\mathrm{py}} \mathrm{H}$-bond which causes weakening of the $\mathrm{N}-\mathrm{H}$ bond involved. ${ }^{32}$ Similar $\mathrm{N}-\mathrm{H}$ bond weakening has also been found in related $\mathrm{N}_{\mathrm{py}}-\mathrm{H} \ldots \mathrm{N}_{\mathrm{py}}$ systems, ${ }^{33}$ such as in the dimer of [(4-benzoylpyridine $\left.)_{2} \mathrm{H}\right]\left(1955 \mathrm{~cm}^{-1}\right) \cdot{ }^{34}$ For comparison, the $\mathrm{O}-\mathrm{H}$ stretching vibration for $\mathrm{MeOH}$ in the solvate $2 \cdot \mathrm{MeOH}$ is observed as a broad band at $3400 \mathrm{~cm}^{-1}$. Negative-ion HR-MS analysis of crystalline $\mathbf{2}$ shows a major peak for $\left[2+\mathrm{BF}_{4}\right]^{-}(1005.1412 \mathrm{Da}$, calcd. $1005.1400 \mathrm{Da})$, adding further support for the presence of the protonated pyridyl groups in $\mathbf{2}$ (Figure S10). A downfield shift of the ${ }^{31} \mathrm{P}\left\{{ }^{1} \mathrm{H}\right\} \mathrm{NMR}$ signal to $154.5 \mathrm{ppm}\left(\mathrm{CD}_{3} \mathrm{CN}\right)$ is observed upon complexation of the phosphine ligand in $\mathbf{2}$ (free ligand: $150.0 \mathrm{ppm}, \mathrm{CDCl}_{3}$ ).

In order to clarify the reduction mechanism, in situ NMR spectroscopic investigations were carried out (Figure 2). One of the key questions in this regard is whether a fluoride-assisted redox reaction is a possible reaction pathway, similar to that observed in the formation of $\mathrm{Pd}^{0}$ phosphine complexes. ${ }^{20-22}$ The ${ }^{31} \mathrm{P}\left\{{ }^{1} \mathrm{H}\right\} N M R$ spectrum of the reaction mixture of bis(methoxy)2-pyridyl-phosphine (1) and [ $\left.\mathrm{Ni}(\mathrm{MeCN})_{6}\right]\left(\mathrm{BF}_{4}\right)_{2}$ in $\mathrm{CD}_{3} \mathrm{CN}$ after 30 mins at room temperature is shown in Figure 2a. No further splitting of the observed resonances is seen in the protoncoupled ${ }^{31} \mathrm{P}$ NMR spectrum, excluding the presence of $\mathrm{P}-\mathrm{H}$ containing by-products. The main signal at $\delta 154.5 \mathrm{ppm}$ is due to the nickel(0) complex $\mathbf{2}$ (a singlet resonance being observed in the ${ }^{31} \mathrm{P}\left\{{ }^{1} \mathrm{H}\right\} \mathrm{NMR}$ spectrum presumably due to the rapid exchange of the $\mathrm{N}-\mathrm{H}$ protons between the $\mathrm{N}$-atoms in the $\mathrm{N}-$ $\mathrm{H} \cdots \mathrm{N} \mathrm{H}$-bonds). Other resonances for P-containing species are also present which indicate that a number of other transformations of ligand $\mathbf{1}$ have also taken place. The broadening of some of these resonances may be due to the presence of residual paramagnetic $\mathrm{Ni}^{\prime \prime}$ and makes any assignment of the by-products difficult. 
One potentially significant observation is the broad resonance at ca. $15 \mathrm{ppm}$, which is typical of $\mathrm{P}^{\vee}$ phosphine oxide derivatives. ${ }^{35-37}$ However, test reactions of 1 with ambient air or water show that both lead to the exclusive formation of the secondary phosphine oxide (MeO)P(O)H(2-py) ( ${ }^{31} \mathrm{P}$ NMR $\delta$ $24.6 \mathrm{ppm},{ }^{1} J_{\mathrm{PH}}=581.6 \mathrm{~Hz}$ ). Since this species is entirely absent in the reaction mixture, adventitious water- or $\mathrm{O}_{2}$-induced $\mathrm{P}^{\prime \prime \prime} \rightarrow$ $P^{V}$ redox reaction ${ }^{17}$ is unlikely to be responsible for the formation of $\mathbf{2}$.

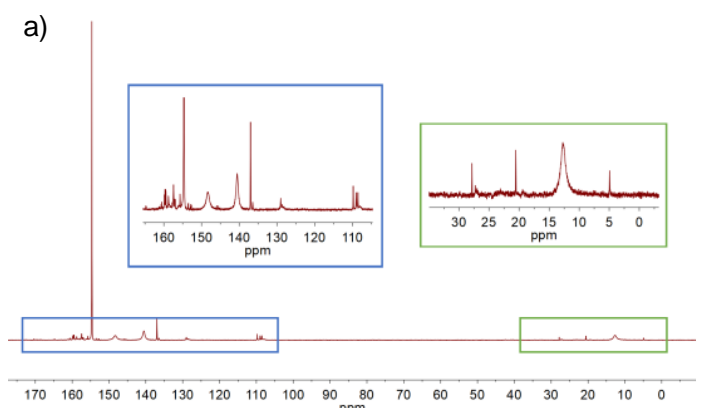

b)
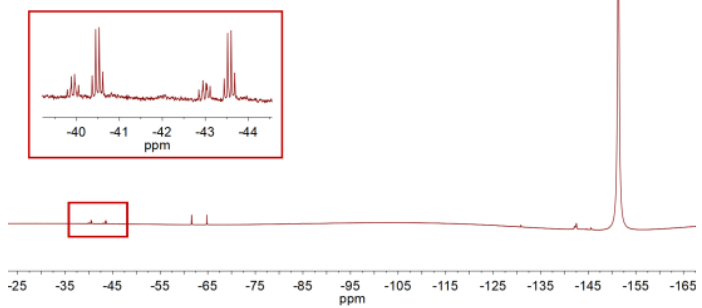

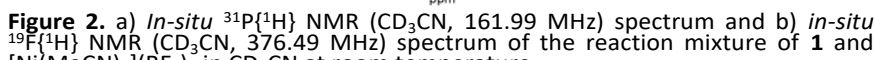
$\left[\mathrm{Ni}(\mathrm{MeCN})_{6}\right]\left(\mathrm{BF}_{4}\right)_{2}$ in $\mathrm{CD}_{3} \mathrm{CN}$ at room temperature.

The ${ }^{19} \mathrm{~F}\left\{{ }^{1} \mathrm{H}\right\}$ NMR spectrum of the reaction mixture is shown in Figure $2 \mathrm{~b}$. The proton-coupled ${ }^{19} \mathrm{~F}$ NMR spectrum is identical. The main signal, a singlet at $\delta-151.9 \mathrm{ppm}$, can be attributed to the tetrafluoroborate anions of the nickel(0) complex 2 . Additionally, two, closely-related low-intensity doublets of (binomial) quartets $(\delta-41.4$ and $-41.9 \mathrm{ppm}$ ) are seen. Both signals comprise one large coupling constant of $1155.8 \mathrm{~Hz}$, which is in the typical range for a one-bond $\mathrm{P}-\mathrm{F}$ scalar coupling, ${ }^{38}$ and smaller coupling constants of 35.0 and $30.9 \mathrm{~Hz}$, which presumably arise from the long-range coupling to three magnetically-equivalent $P$ atoms. The possible origin of these signals could be nickel complexes with fluorinated and unfluorinated ligand molecules, e.g., the $\mathrm{Ni}^{0}$ complex $\left[(\mathbf{1} \mathrm{F}) \mathrm{Ni}(\mathbf{1})_{3}\right]^{-}$ (species A, Scheme 3). In addition, a doublet at $-63.2 \mathrm{ppm}$ with a coupling constant of $1203.2 \mathrm{~Hz}$ is also observed, which again indicates the presence of a P-F moiety. Traces of other Fcontaining species in the region of -130 to $-150 \mathrm{ppm}$ show no distinct splitting. Although none of these species can be unambiguously identified on this basis, the NMR spectroscopic data provide a strong indication (i.e., the presence of a $\mathrm{PV}$ resonance and $\mathrm{P}-\mathrm{F}$-containing by-products) that the formation of $\mathbf{2}$ involves a fluoride-induced redox process, involving the decomposition of the $\mathrm{BF}_{4}^{-}$anion, related to that observed previously for Pd". Further support for this conclusion comes from the in situ NMR spectroscopic study of the reaction of $\mathrm{NiCl}_{2}$ in place of $\left[\mathrm{Ni}(\mathrm{MeCN})_{6}\right]\left(\mathrm{BF}_{4}\right)_{2}$ (in thf), which showed no apparent formation of $\mathbf{2}$.

Based on previous studies of the formation of $\mathrm{Pd}^{0}$ complexes and on the basis of the spectroscopic evidence, a tentative mechanism for the formation of $\mathbf{2}$ is shown in Scheme 3. In this process, the decomposition of the $\mathrm{BF}_{4}{ }^{-}$anion into $\mathrm{BF}_{3}$ and $\mathrm{F}^{-}$is most likely to be driven thermodynamically by the formation of strong $\mathrm{P}-\mathrm{F}$ bonds and by the potential formation of a $\mathrm{BF}_{3}$ adduct with the Lewis basic 2-pyridyl groups of 1 . The nucleophilic attack of $\mathrm{F}^{-}$on to the $\mathrm{Ni}(\mathrm{II})$-bonded phosphine leads to the formation of intermediate $\mathbf{A}$, which contains a hypervalent $\left[(\mathrm{MeO})_{2}(2-\mathrm{py}) \mathrm{PF}\right]^{-} \mathrm{P}^{\prime \prime \prime}$ anion (Scheme 3 ). A twoelectron transfer from $\mathrm{P}$ to $\mathrm{Ni}$ then yields the nickel( $(0)$ complex $\mathbf{2}$ and $\mathbf{1} \mathrm{F}^{+}$(and subsequently $\mathbf{1} \mathrm{F}_{2}$ ). The existence of the $1 \mathrm{~F}^{+}$cation was confirmed in a separate NMR experiment in which the phosphine ligand was reacted with NFSI ( $\mathrm{N}$-fluorobenzenesulfonimide) in $\mathrm{MeCN}\left(1: 1,{ }^{31} \mathrm{P}\left\{{ }^{1} \mathrm{H}\right\} \delta 9.0 \mathrm{ppm}\right.$, ${ }^{1} J_{\mathrm{PF}}=1055.3 \mathrm{~Hz}$ ). The difluorophosphorane $\mathbf{1 F}_{2}$ could not be synthesised via this route.

$$
\begin{aligned}
& {\left[\mathrm{Ni}^{\prime \prime}(\mathrm{MeCN})_{6}\right]\left(\mathrm{BF}_{4}\right)_{2} \stackrel{4 \times \text { phosphine } 1}{\longrightarrow}\left[\mathrm{Ni}^{\prime \prime}(1)_{4}\right]\left(\mathrm{BF}_{4}\right)_{2}} \\
& \downarrow-\mathrm{BF}_{3}
\end{aligned}
$$

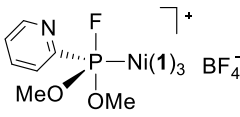

$$
\begin{aligned}
& \text { A } \\
& -1 F_{2} /-B_{3} \\
& {\left[\mathrm{Ni}^{0}(1)_{3}\right] \stackrel{+1}{\longrightarrow}\left[\mathrm{Ni}^{0}(1)_{4}\right]}
\end{aligned}
$$

Scheme 3: A possible pathway to the formation $\mathrm{Ni}^{0}$ using the phosphine ligand $\mathbf{1}$.

Our studies have not allowed us to identify unequivocally the proton source which is ultimately responsible for the formation of the $\left[\left\{(\mathrm{MeO})_{2} \mathrm{P}(2-\mathrm{py}-\mathrm{H})\right\}_{2}\left\{(\mathrm{MeO})_{2} \mathrm{P}(2-\mathrm{py})\right\}_{2} \mathrm{Ni}\right]^{2+}$ cation. However, this is likely to be the $\mathrm{CH}_{3} \mathrm{CN}$ solvent itself, and it has been shown previously that $\mathrm{C}-\mathrm{H}$ activation of $\mathrm{MeCN}$ can occur in the presence of zero-valent nickel bis(dialkylphosphino)ethane fragments. ${ }^{39-41}$ It can be noted in this regard that $\mathbf{2}$ is formed in the reaction mixture before crystallisation from $\mathrm{MeOH}$ (Figure 2a) so that this is not the proton source. Complex $\mathbf{2}$ can, however, also be obtained using $\mathrm{MeOH}$ as the reaction solvent, albeit in lower $(27 \%)$ isolated crystalline yield. The complex is again not formed in this case using $\mathrm{NiCl}_{2}$.

In summary, an unexpected in situ reduction of $\mathrm{N}^{\mathrm{ill}} \rightarrow \mathrm{Ni}^{0}$ is observed in the reaction of bis(methoxy)-2-pyridyl-phosphine 1 with $\left[\mathrm{Ni}(\mathrm{MeCN})_{6}\right]\left(\mathrm{BF}_{4}\right)_{2}$. This synthetic strategy allows the isolation of a phosphine $\mathrm{Ni}^{0}$ tetrakis-phosphine complex without the addition of any external reducing agent or the use of a labile $\mathrm{Ni}^{0}$ precursor, providing a very convenient one-step route to reactive nickel( 0 ) complexes. Our results support a mechanism involving fluoride-assisted oxidation of the phosphorus atom caused by the decomposition of the tetrafluoroborate anion. Complex $\mathbf{2}$ not only provides a potential $\mathrm{Ni}^{0}$ reagent for homogeneous catalysis, but is also of 
interest in the field of electro-catalysts, as it possesses a noncoordinating pendant amine functionality in the secondary coordination sphere of the ligand backbone. ${ }^{42-45}$

We thank the Studienstiftung des deutschen Volkes (S.H., T.G). the Leverhulme Trust (DSW, RG-R), the Spanish MINECO$A E I$ and the EU (ESF) for a Ramon y Cajal contract (RG-R, RYC2015-19035) and the Spanish MCIU (RG-R, PGC2018-096880-A100, MCIU/AEI/FEDER, UE), and Selwyn College Cambridge (Walters-Kundert Studentship, J.E.W.).

\section{Conflicts of interest}

There are no conflicts to declare.

\section{References}

1 S. Z. Tasker, E. A. Standley and T. F. Jamison, Nature, 2014, 509, 299-309.

2 M. Tobisu, T. Shimasaki, N. Chatani and N. Angel, Angew. Chem. Int. Ed., 2008, 47, 4866-4869.

3 B. L. H. Taylor, E. C. Swift, J. D. Waetzig and E. R. Jarvo, J. Am. Chem. Soc., 2010, 133, 389-391.

$4 \quad$ J. Zhou and G. C. Fu, J. Am. Chem. Soc., 2003, 125, 1472614727.

5 K. Amaike, K. Muto, J. Yamaguchi and K. Itami, J. Am. Chem. Soc., 2012, 134, 13573-13576.

6 H. Shiota, Y. Ano, Y. Aihara, N. Fukumoto and N. Chatani, J. Am. Chem. Soc., 2011, 133, 14952-14955. T. M. Gøgsig, J. Kleimark, S. Nilsson Lill, S. Korsager, A. T. Lindhardt, P.-O. Norrby and T. Skrydstrup, J. Am. Chem. Soc., 2011, 134, 443-452. E. A. Standley and T. F. Jamison, J. Am. Chem. Soc., 2013, 135, 1585-1592. S. Z. Tasker, A. C. Gutierrez and T. F. Jamison, Angew. Chem. Int. Ed., 2014, 53, 1858-1861. R. M. Moslin, K. Miller-Moslin and T. F. Jamison, Chem. Commun., 2007, 4441-4449. 2007, 130, 469-471.

12 A. J. Nett, S. Canellas, Y. Higuchi, M. Robo, J. M. Kochkodan, M. T. Haynes, J. W. Kampf and J. Montgomery, ACS Catal., 2018, 8, 6606-6611.

13 M. Aresta, C. F. Nobile and A. Sacco, Inorg. Chim. Acta, 1975, 12, 167-178.

14 O. Kühl, P. C. Junk and E. Hey-Hawkins, Z. Anorg. Allg. Chem., 2000, 626, 17-20.

15 T. Tanase, H. Takahata and Y. Yamamoto, Inorg. Chim. Acta, 1997, 264, 5-9.

16 J. Mautz, K. Heinze, H. Wadepohl and G. Huttner, Eur. J. Inorg. Chem., 2008, 2, 1413-1422.

17 R. S. Vinal and L. T. Reynolds, Inorg. Chem, 1964, 3, 10621063.

18 M. Meier and F. Basolo, in Inorg. Syn., ed. R. J. Angelici, John Wiley \& Sons, 28th edn., 1990.

19 T. M. Balthazor and R. C. Grabiak, J. Org. Chem., 1980, 45, 5425-5426.
M. R. Mason and J. G. Verkade, Organometallics, 1992, 11, 2212-2220.

M. R. Mason and J. G. Verkade, Organometallics, 1990, 9, 864-865.

P. A. McLaughlin and J. G. Verkade, Organometallics, 1998, 17, 5937-5940.

V. V. Grushin, Chem. Rev., 2004, 104, 1629-1662. R. F. Jordan, W. E. Dasher and S. F. Echols, J. Am. Chem. Soc., 1986, 108, 1718-1719.

J. Reedijk, Comment. Inorg. Chem., 1982, 1, 379-389. S. Hanf, R. García-Rodríguez, A. D. Bond, E. Hey-Hawkins and D. S. Wright, Dalt. Trans., 2016, 45, 276-283.

S. Hanf, R. García-Rodríguez, S. Feldmann, A. D. Bond, E. Hey-Hawkins and D. S. Wright, Dalt. Trans., 2017, 46, 814824.

S. Hanf, A. L. Colebatch, P. Stehr, R. García-Rodríguez, E. Hey-Hawkins, D. S. Wright, Dalton Trans., in press. J. Y. Yang, R. M. Bullock, W. J. Shaw, B. Twamley, K. Fraze, M. R. DuBois and D. L. DuBois, J. Am. Chem. Soc., 2009, 131, 5935-5945.

J. Y. Yang, S. E. Smith, T. Liu, W. G. Dougherty, W. A. Hoffert, W. S. Kassel, M. R. DuBois, D. L. DuBois and R. M. Bullock, J. Am. Chem. Soc., 2013, 135, 9700-9712.

A. Cryst, B. Y. C. Glidewell and H. D. Holden, Acta Cryst. B., 1982, 667-669.

A. Novak, in Hydrogen bonding in solids correlation of spectroscopic and crystallographic data, 1974, pp. 177216.

D. Jones and D. F. Evans, Nature, 1963, 4890, 277-278. F. A. Mautner and M. A. S. Goher, Polyhedron, 1998, 18, 553-559.

I. Pryjomska, H. Bartosz-Bechowski, Z. Ciunik, A. M. Trzeciak and J. J. Ziółkowski, Dalt. Trans., 2006, 0, 213-220. D. M. Roundhill, R. F. Sperline and W. B. Beaulied, Coord. Chem. Rev., 1978, 26, 263-279.

M. R. J. Vallée, P. Majkut, I. Wilkening, C. Weise, G. Müller and C. P. R. Hackenberger, Org. Lett., 2011, 13, 5440-5443. J. M. Bayne, M. H. Holthausen and D. W. Stephan, Dalt. Trans., 2016, 45, 5949-5957.

T. A. Ateşin, T. Li, S. Lachaize, W. W. Brennessel, J. J. García and W. D. Jones, J. Am. Chem. Soc., 2007, 129, 7562-7569. J. J. Garcia, N. M. Brunkan and W. D. Jones, J. Am. Chem. Soc., 2002, 124, 9547-9555.

M. E. Evans, T. Li and W. D. Jones, J. Am. Chem. Soc., 2010, 132, 16278-16284.

J. Y. Yang, R. Morris Bullock, W. G. Dougherty, W. S. Kassel, B. Twamley, D. L. DuBois and M. R. DuBois, Dalt. Trans., 2010, 39, 3001-3010.

B. R. Galan, J. Schöffel, J. C. Linehan, C. Seu, A. M. Appel, J. A. S. Roberts, M. L. Helm, U. J. Kilgore, J. Y. Yang, D. L. DuBois and C. P. Kubiak, J. Am. Chem. Soc., 2011, 133, 12767-12779.

R. Tatematsu, T. Inomata, T. Ozawa and H. Masuda, Angew. Chem. Int. Ed., 2016, 55, 5247-5250.

S. Lense, M.-H. Ho, S. Chen, A. Jain, S. Raugei, J. C. Linehan, J. A. S. Roberts, A. M. Appel and W. Shaw, Organometallics, 2012, 31, 6719-6731. 
